\title{
DROWNING- INVESTIGATION AND DEATH SIGNS
}

\author{
Dr. Dnyaneshwar Sonba Naykodi \\ Associate Professor Agadtantra Deptt. Ashvin Rural Ayurved College,Manchihill \\ (Received on Date: $27^{\text {th }}$ July 2020 \\ Date of Acceptance: $11^{\text {th }}$ August 2020 \\ Date of Publish: $4^{\text {th }}$ September 2020) \\ Email: drnaykodids@gmail.com
}

\begin{abstract}
Investigation of bodies recovered out of water comprises an important proportion of the medico-legal requests. However, the key question whether the victim died due to "true" drowning can frequently not easily be solved. In addition, the diagnosis of hydrocution is even more difficult. In this manuscript, we are discussing regarding the drowning investigation and death signs.

Keywords: Drowning, Investigation and death signs

\section{No: of References: 05}




\section{INTRODUCTION}

Drowning is the process of experiencing respiratory impairment from submersion or immersion in liquid.[1] This process is a continuum beginning with respiratory impairment as the victim's airway goes below the surface of the liquid (submersion) or when water splashes over the face (immersion). If the victim is rescued at any time, the process of drowning is interrupted, resulting in a nonfatal drowning. Any submersion or immersion incident without evidence of respiratory impairment (aspiration) should be considered a water rescue rather than a drowning. Terms such as "near-drowning," "dry or wet drowning," "active and passive drowning," "secondary," and "delayed onset of respiratory distress" should not be used

The inhaled water enters the alveolar spaces of the lungs and destroys the surfactant inducing pulmonary edema with the transudation of protein-rich fluid into the alveolar spaces. The surfactant washout decreases the lung compliance and ventilation-perfusion mismatch resulting to an hypoxemia secondary of non oxygenation of blood flowing through underventilated portions of the lung. A non cardiogenic pulmonary edema will result with secondary metabolic acidosis. This is the main pathophysiological mechanism of drowning and the fluid and electrolyte shifts are quite secondary.

It was stated that fresh water is hypotonic and hyponatremic relative to blood inducing, after inhalation, a movementt of water from the alveoli into the blood and movement of sodium from the blood into the alveoli. These changes induce haemodilution, hypervolemia, hypnonatremia, hyperkalemia and haemolysis (Jeanmonod et al., 1992). As the sea water is very hypertonic relative to the blood, the water movement goes from blood into the alveoli and the electrolytes (sodium, chloride, magnesium) from the alveoli into the blood. The consequences of the sea water drowning should be haemoconcentration, hypovolemia and hypernatremia. The biochemical tests that proposed to assess the diagnostic of drowning are based on these fluids and electrolytes shifts. It is during the phases where water is penetrating from the alveoli into the blood circulation that particles like diatom passing through the alveolarcapillary interface before reaching internal organs.

A vagal reflex may be also induced by inhalation of water, it will increase peripheral airway resistance with pulmonary vasoconstriction, decreased lung compliance and reduction of ventilation - perfusion ratios (Ornato, 1986).

An intense stimulation of nerve endings at the skin, the mucosa of the ear drum, the pharynx or the larynx by cold water can lead to a cardiac reflex arrest. It was assumed that $10 \%$ of the drowned humans die after laryngospasm or breath-holding without actually aspirating fluid (Ludes \& Fornes, 2003). A discussion was also hold about the volumes of inhalated water and 
the effect on the circulation. In drowning, the inhalated volume of water can range, from relatively small to very large. It has been showed that small amount of water, particularly cold water, may induce vaso vagal reflex or cardiac arrest reflex. When great amounts of water are inhalated and pass through the alveolar-capillary interface and enter the circulation, the phenomenon of destruction of surfactant and of the alveoli architecture leads to asphyxia. During the entering of water into the blood stream, the diatoms present in the drowning fluid may reach the internal organs. The microscopic investigations must be performed on all the organs of non putrefied bodies in the aim to make the difference between a death by drowning and other causes of death. The lung examinations can show over-distension of the alveoli, thinning of the alveolar septa and compression with narrowing of the capillary network (Pounder, 2005).

The modifications in lungs are heterogeneous distributed and multiple sections must be performed to assess the diagnostic. In fact the microscopic appearance may be entirely normal in some part of the lungs.Several staining techniques must be performed such as the staining for elastic fibers (orcein ) and reticulin fibers (Fornes et al., 1988 ; Ludes \& Fornes, 2003). The examination of other organs (brain, heart, liver) shows none specific histological changes indicative of hypoxia such as acute congestion and swelling of the capillary endothelia.

Biological tests
The chemical changes in plasma after drowning were based on the fluid and electrolyte shifts after the penetration of either sea or fresh water in the alveoli and in the blood stream (Modell \& Davis, 1969). It was proposed the measurement of the specific gravity of blood, of the concentration of sodium, chloride and potassium. For the electrolytes, the diagnosis of drowning was based on changes of these electrolytes between the blood samples taken from the right versus left ventricle (Bray, 1985; Couteselinis \& Boukis 1976; Karkola \& Neittaanmaki, 1981). Such electrolyte shifts were described in many other causes of death and do not provide reliable evidence of drowning.A special mention must be made for the blood strontium analysis. The toxicological analysis are performed to show the presence of medicaments or alcohol, taken before death in suicidal or accidental conditions and to determine the serum level of strontium which is described as a good parameter of drowning in sea water (Piette \& Timperman, 1989). In case of fresh water drowing, the water concentration of strontium must be higher than the serum concentration to be a valuable parameter in favour of drowning. Authors such as Kane et al. (1996, 2000) and Nübel et al. (1997) proposed the detection by molecular biology techniques of the $16 \mathrm{~S}$ rRNA subunits of ribosomal RNA for plankton detection in tissues samples indicating an active water inhalation and may assess the diagnostic of drowning. According to these authors, the sequence comparison of the variable regions of $16 \mathrm{~S}$ rRNA could 
provide sufficient information to allow the discrimination of both close and distant phylogenetic relationships.Abe et al. (2003) and Suto et al. (2003) proposed the detection of chlorophyll-related genes of Euglena gracilis and Skeletonema costatum to identify plankton in the victim's tissues. It is important to emphasize that these methods give only qualitative results (He et al., 2008) but the quantitative approach can only be achieved by the diatom test which may also give an indication of the site of drowning.In fact, diatoms can be considered as particles present in the submersion water which are inhalated during drowning and once in the blood stream which reach the closed organs. Under strict extraction and identification conditions, these particles are good markers of drowning.Diatoms are unicellular algae belonging to the class of bacillariophycae which includes more than 15000 species living in fresh, brakish or sea water. The skeleton of these algae is called a frustule which is constituted by two valves fitting together to enclose the cytoplasm (Ludes \& Fornes, 2003) and made of hard silice.Due to this hard silicaceous skeleton, diatoms can be recovered from putrefied or burnt tissues by either enzymatic or acid digestion (Ludes et al., 1994). The identification of these algae is based on the structure of their valves showing different symmetry allowing the distinction of two main groups namely the centric diatoms and the elongated or pennate diatoms.After a long period of time where the use of the diatom test was very controversial due to false positive results linked to the presence of diatoms in closed organs of nondrowned victims

\section{REFERENCES}

B. Brinkmann, Tod im Wasser, in: B. Brinkmann, B. Madea(Eds.), Handbuch Gerichtliche Medizin 1, Springer, Berlin,2004, pp. 797-819.

J. Chr. Giertsen, Drowning, in: J.K. Mason, B.N. Purdue(Eds.), The Pathology of Trauma, Arnold, London, 2000,pp. 253-264.

P. Brouardel, Ch. Vibert, Etude sur la submersion, Annalesd'Hygie 'ne Publique et de Me'decine Le'gale 3-4 (1880) 452470.

T.G. Schwär, Drowning: its chemical diagnosis. A review,Forensic Sci. 1 (1972) 411-417.

R. Jeanmonod, Ch. Staub, B. Mermillod, The reliability ofcardiac haemodilution as a diagnostic test of drowning, For-ensic Sci. Int. 52 (1992) 171-180.

C.V. Wetli, R.E. Mittleman, U.J. Rao, Practical ForensicPathology, Igaku-shoin, New York, Tokyo, 1988, p. 71.

E. Stockis, Recherches sur le diagnostic me'dico-le'gal de lamort par submersion, Annales de la socie'te'de me'decine le'galede Belgique 20 (1909) 71-220.

E. Stockis, Le diagnostic de la mort par submersion par lame'thode du planchton cristallin, Annales de me'decine le'galede criminologie et de police scientifique 1 (1921) 43-48. 
G. Corin, A propos du diagnostic de la mort par submersion,Annales de la socie'te'de médicine le'gale de Belgique 20 (1909)375-377.

G. Corin, E. Stockis, Le diagnostic me'dicole'gal de l'asphyxiepar submersion, Annales de la socie'te'de me'decine le'gale deBelgique 20 (1909) 14-23.

T. Bajanowski, B. Brinkmann, A.M. Stefanec, R.H. Barckhaus, G. Fechner, Detection and analysis of tracers in experimentaldrowning, Int. J. Legal Med. 111 (1998) 57-61.

A.J. Peabody, Diatoms and drowning. A review, Med. Sci. Law20 (1980) 254-261.

B. Schellmann, W. Sperl, DiatomeenNachweis im Knochen-mark (Femur)
Nichtertrunkener, Z. Rechtsmed. 83 (1979)319-324.

G. Ranner, H. Juan, H. Udermann, Zum Beweiswert vonDiatomeen im Knochenmark beim Ertrinkungstod, Z.Rechtsmed. 88 (1982) 57-65.

N.E. Antonenko, Diatom analysis lives on, Can. Soc. ForensicSci. J. 20 (1987) 101-102.

J. Timperman, The diagnosis of drowning. A review, ForensicSci. 1 (1972) 397-409.

G. De Blust, Natuurbeheersproblemen: een natuurreservaatstaat niet alleen! in: $M$. Hermy (Ed.), Natuurbeheer, M. Vande Wiele, Brugge, 1989, pp. 31-45.

D. Chardez, J. Lambert, Protozoaires cilie's et thanatologie,Forensic Sci. Int. 28 (1985) 83-101 